\title{
酒類の製造中に酵素剮を使用 することについて
}

昭和 43 年 12 月 18 日付間酒 1 79 の通達により, 酵素剂をこうじと 併用する場合の取扱いが改正されたが，この間の経緯と今後の酵素剂利 用の方について述べていただいた。さらに製品の多様化に対してどの ような姿勢で税法の検討をすすめているかという興味ある問題について も所信を明らかにしていただいた。

小武山 温 之/国税庁醸造試験所

\section{まえがき}

酒類業界にも最近資本の自由化の問題が叫ばれ, 昨年 はビールが, 今年に入って清酒業が 100\% 自由化に, そ の他の酒類業は $50 \%$ 資本の自由化が決りました。さら にウイスキー等の輸入の自由化も間近く, いよいよ国際 的競争の矢面に酒類業界がたったわけです。

清酒業については, 近代化第一次 5 か年計画が終って 業界の構造改善を前提とした第二次 5 か年計画が着々と 進められております。

酒造業が食管から離れて自由化され，原料米の割当て 制度も組合が行なら生産規制といら線で検討されていま すが，5か年後には自由化する前提になっているとき， 清酒業者特に中小，零細企業に生きる道は非常に戦しく， 自分の努力によって自分の道を切りひらいて行く他に方 法はありません。今後経営の面で永続性, 発展性, 収益 性が強く要求されるのは当然で, 強力的かつ効率的な経 営組織と販売活動が必要であります。

最近，全国的にグループを造って，同一銘柄で新製品 の販売がいろいろと行なわれはじめましたが, 非常に結 構なことだと思っております。

しかし, 販売活動の前提は商品の優良性であり, 品質 の均一性, 優良化をはかることが第一だと思います。併 せてコストダウンを如何にしてはかるか等の問題もあり ます。また一方では品質の多様化等, 他酒類との競合打 開をはかる努力がされなければなりません。こんな時期 にこそ高度な技術と創意工夫が要求されることはいらま でもありません。

清酒の多様化の問題としましては, 最近炭酸ガス入り の清酒がパンチメートといら名で 6 月 1 日付で全国一斉
に発売されます。これにクエン酸添加を認める問題，ま た，35\% あるいは $25 \%$ の高酒精分清酒の販売を認める 問題も方りした。さらに合成清酒では清酒メートルー 30 という極端に甘口な合成清酒の販売を認める問題な どがあります。

今回は酵素特集号ということでありますから，酵素剤 を酒類の製造中に使用する場合の取り扱い改正した点に ついて，どのような経路で改正したのか，また今後はど のような方向で進むべきかといらことを中心にして，現 在の酒類の添加物品の改正問題, あるいは新製品等を どのように認識して行くか等について話したいと思い ます。

\section{1. 酒類製造中の醰素凨の利用について}

\section{1. 改正された内容}

酵素剂を，こうじと併用する場合の取扱いについては 昭和 43 年 12 月 18 日間酒 1 79 の通達によって次のよ うに改正を行ないました。

「酵素剂をこうじと併用する場合において, 酵素剤の 使用総量が，原料中のでんぷんの重量の 2000 分の 1 以 下であるとさは，当該酵素剤を酒類の原料として，取り 扱わないものとする。」

ですから，今回の改正によって今までは酒類の製 造 中，こうじと併用する場合に，でんぷん分解酵素剂のみ 添加が認められていたものを，どんな酵素剂でも添加で きるよらになったわけです。ただし，酒類の製造にこう じを使用するのは, 清酒および合成清酒, みりん, リキ ユ一ル類の中の白酒 (注に説明), 雑酒 (赤酒, 地酒, 濁 酒等）の他，乙類しょらちゅらの製造に用いられますが， しょうちゅうは,アルコール含有物を蒸留した酒類です 
から，酵素剤制限はありません。また合成清酒の調味液 製造の場合は，米以外の原料は使用制限しておりません し, 雑酒の場合は原料制限はありません。したがって今 回の改正に関係のあるのは, 酒類のうち清酒, みりんお よび白酒の製造の場合であるということがいえます。

\section{2. 改正前の取り扱い内容と問題だった点}

酵素剤を酒類に使用することは「でんぷん分解酵素を 使用する場合の取扱い」(昭和 38 年 4 月 16 日付間酒 1 〜40）によって次のように認めておりました。

「こうじのでんぷん糖化力を助成して, 糖化能率を上 昇させるため, 微量（でんぷん量に対して，その 2000 分の 1 以下）のでんぷん分解酵素剂を，こうじと併用す ることは，酒類の品質の維持执よび，取締上に支障のな い限り, 認めて差しつかえないことに取り扱うものとす る。」

この通達の主要な点は, 次の 4 点であります。

（1）でんぷん分解酵素剤をでんぷん量に対して2000 分の 1 までは, 添加を認める。

（2）こうじと併用の場合。

（3）こうじのでんぷん糖化力を助成する。

(4) 取り締り上支障あれば認めない。

以上のうち, (4)は当然のことでありますから論外と しても，(1)，(2)，(3)についてはいろいろと解釈に 違いがありました。例えば，

（1）については, でんぷん量とは清酒の場合, 白米を 指すのか, 水分を除いて考えるのか, 白米中のでんぷん だけを指すとすれば，水分の外に蛋白，脂肪の量も抜い て考えるべきであるのか。

( 2 )こらじと併用とは酵素剂を使用する時は, 同時に 必ずこうじを使用しなくてはならないのか。

（3）については, 助成といっているが, 一部代替えし ているのではないか。

これらの疑いに対して酒税通信第 75 号「でんぷん量 の計算について」（昭和 41 年 12 月 22 日）によって通達 の解釈を明確にしました。すなわち，（2）については， 必ずしも，こらじと同時に使用しなければならないと解 釈すべきではなく, 例えば, 清酒醇造で, 四段掛けに甘 酒四段を行なら場合，1仕込区分ごとのでんぷん量に対 して 2000 分の 1 の範囲内であれば，枝桶で糯米にでん ぷん酵素剂のみを使用して分解してもさしつかえないこ

注：白酒は昭和 37 年 4 月からリキュール類に入りま したが，それ以前に免許したものは旧酒税法第三条 8 号「白酒の定義」が生きており，原料の制限があ ります。37 年以降の免許についても原料の制限 (み りんと同じ）があります。したがって白酒製造の場 合酵素剤の使用量む 2000 分の 1 の範囲内です。
とを明確にしました。

(1)については，「でんぷん量に対してその 2000 分 の $1 」$ の計算に当っては, 米（1 仕込みに使用する白米 をいら）については, でんぷん量率を $80 \%$ とし, その 他の原料については，酒税事務規定第 217 号様式別表所 揭の乗率(次表参照のこと)に基づき計算した率をもって， それぞれの原料量からでんぷん量を算出のらえ, 2000分 の 1 以上であるかる判定することとする。

酒類用原料の切干さつまいも換算表

\begin{tabular}{|c|c|c|c|}
\hline 品 & 乗 率 & 品 & 乗 率 \\
\hline 切干さつまいる & 1.00 & あわ ね か & 0.79 \\
\hline 大 麦 & 1.04 & 麦 12 か & 0.70 \\
\hline ひ き 割 & 1.08 & ひ $え ぬ$ か & 0.72 \\
\hline ひき割 小麦 & 1.08 & ばれいしょ & 0.22 \\
\hline 研 小 麦 & 1.04 & ぞ ん く & 0.35 \\
\hline 麦 & 1.18 & 菊 い & 0.22 \\
\hline b & 0.59 & そ 鉄 & 0.52 \\
\hline そ ば & 1.00 & キャッサバルート & 1.04 \\
\hline 床さつまいる & 0.19 & 球 根 & 0.79 \\
\hline さつまいもの皮(干) & 0.52 & ぼたんくず & 0.59 \\
\hline 、 \& 粉 & 1.04 & क $\quad$ म & 0.26 \\
\hline ん & 1.35 & ほ うききび & 0.87 \\
\hline 二 番 & 1.08 & タン = ンかす & 0.71 \\
\hline 土肉でん粉 & 0.81 & 彼 岸 花 根 & 0.32 \\
\hline あ わ & 1.04 & す ま & 0.68 \\
\hline 製あ & 1.30 & 麦 芽 根 & 0.47 \\
\hline 之 & 0.96 & キャッサバかす & 0.60 \\
\hline と 5むろこしの皮 & 0.52 & みりんかす & 0.76 \\
\hline$こ 5 り や ん(マ イ \triangleright)$ & 0.92 & 清 酒 か す & 0.33 \\
\hline き び 粉 & 1.00 & 生さっまいる & 0.33 \\
\hline W & 0.52 & 米 & 1.08 \\
\hline いな & 0.58 & 糖 み つ & 0.66 \\
\hline 12 & 1.04 & でん粉かす（干） & 0.60 \\
\hline 赤 $\quad 2 \quad$ 力 & 0.81 & と 5 \& $こ し$ & 0.98 \\
\hline こ5りやんぬか & 0.39 & なつめやし(デーッ) & 0.82 \\
\hline
\end{tabular}

（3）については, 糖化力を助成するのであって, 代替 ではありません。代替ということになれば原料として扱 らべきだと解釈しております。なおこの問題について は，後で述べたいと思います。

\section{3. 今回の改正に至るまでの経緯}

（1）新たに繊維素分解酵素剂を認めることの検討 でんぷん分解酵素剤の使用については前述の通信で問 題が解決しましたが, 一昨年, 昨年の造りでは, 内地米 が不足していたので, 清酒醸造に内地米の他に加州米, 普通外米なども使われるよらになり，また今酒造年度の 造りでは，古米の使用が大きく取り上げられました。古 米等を使用して清酒を醸造しますと搾り粕に裏打ちが出 るといらことは前からいわれておりましたが，この解決 方法として繊維素分解酵素剂の利用が醸造試験所第 5 研 究室で明らかにされ，この酵素剂の使用を是非認めてほ しいという要望があり，認めることが業界の利益になる といら線で検討いたしました。なおこの際次の点も併せ て検討されました。

（2）各種酵素剤の酵素成分内容についての検討 
イ・たんぱく分解酵素剤使用に対する検討

数年前から全国の酒造技術機関合同会議の席上で，た んぱく質分解酵素剂を酒母の製造などで是非使わせてほ しいといら要望がありましたのでこの際併せて検討しょ らといらことになりました。

口 各種酵素片の検討

いろいろ検討した結果、でんぷ几分解酵素剂にも液化 酵素と糖化酵素の他にたんぱく分解醭素も含まれておれ ば，脂肪分解酵素も含んでいることが明らかになりまし た。さらに瀻維素分解酵素剂や，たんぱく分解酵素剂に は相当多量のでんぷん分解酵素の含有が明白になりまし たので, 新しく纎維素分解酵素剤等を認めるのなら，こ の際全部の酵素剂について使用を認めることにしてはど らかということになりました。

(3) 酵素剂の使用量の検討

各種酔素剤を認める場合, 酵素剂の効果を十分に期待 するなら酵素剂每に 2000 分の 1 づつを認めるべきでは ないかといら意見や，この際酵素剤の使用量を無制限に してはどうかといら意見がありました。

酵素剤の量を無制限にする点については現在でんぷん 分解酵素剤は $1 \mathrm{~kg}$ で市価 7,000 8, 000 円位する高価 なものです。したがって力価（酵素の強さ）さ決めて 打けばそんなに多く 1 仕込み使用されることもないか ら, 制限量をはずしてはどうかという意見がありまし た。

この件については, 現在の酵素製造業者にしぼると か, 酵素力価をはっきりさせる必要があるとかいろいる と意見が出ましたが, 結局現在の段階では, こうじの分 解力の助成であるから，2000 分の 1 にしておくといら ことになりました。

ですかから現段階では醸造中にどんな酵素剂を使用して も差しつかえありませんが，総量としては 1 仕込みので んぷん量の 2000 分の 1 の範囲内であることはいらまで もありません。しかも製造にこらじを使用する場合しか 添加できませんから，前述したように関係のある種類は 清酒, みりんおよび白酒の製造だけです。

\section{4. 現在の法規, 通達等との問題点について}

（1）「酒類保存のため酒類に混和できる物品」との 問題。

酒類のおり下げ剂等には，いわゆる，長官指定告示物 品である酵素が広く使われて拉ります。なお，ここで認 められている酵素は会社の商品名であげられています。 例壳ば, クラリン $\mathrm{S}$, パパイン, ラピターゼなどはいず れも，おり下げ剤でたんぱく分解酵素に入るものです。

また果実面について指定されているスクラーゼ，ペク チノール，タカミネペクチナーゼ等はいずれもペクチン
分解酵素の各会社の商品名です。

なぜ商品名になっているかについては, 酵素剤の内容 成分が少しつづ違うことと, 商品名の方が使用の面で安 全であるためです。一般酵素名にしますと，どこの会社 の酵素剤も認めたことになってしまらからです。

なお，この指定物品の規定は，酒類に他の物品を混和 すれば別の種類または品目の酒類製造になってしまうの を製造とみなさず，混和前の種類の種類または品目とみ なす規定であり，製成された酒類の品質保持のために使 用するものであり，今回使用を認めた酵素剂は酒造の合 理化と技術の発展をはかるために酒類の製造過程での使 用を認めたものですから根本的に使用前途が違っており ます。

（2）果実酒の製造工程中，果実のペクチン質の分解 を促進するために加える酵素㓮との関連

果実に含まれるぺクチン質を分解するために果実酒の 製造工程中に加える酵素剤(スクラーゼ, ペクチノール) 等は原料として認められていませんから, 酵素剂をこう じと併用する場合の通達の 2000 分の 1 以下の定めにか かわらず 2000 分の 1 を越えて使用できます。（現在使 用されている量は 1000 分の 1 から 2000 分の 1 です)。

もちろんこうじと併用しない場合でも使用できる果実 酒特有の取扱いと解釈すべきです。

\section{5. 醭素戍利用の今後の方向}

\section{(1) 酒類酵素剂協会について}

酒造に使用されている市販酵素剤は, 昨酒造年度は 4 トン位のものでありましたが，酵素剤の品質が製造業者 によって差違があり，このままでは使用者の酒類業者に も迷惑がかかるのではないかということから清酒中央会 の要望も㐫って, 今年当初に酒類酵素剤協会が発足しま した。

この協会では会員が自主的に品質の面で均一な優秀製 品を廉価に酒類業者に供給する方針のもとに，酵素凨の 酵素力価について相当高い力価を決めているだけでな く, 製品中の水分，重金属等についても厳しい規定を設 けて拈ります。なお，この検査の空口は日本醸造協会で す。

（2）酵素剂使用の考方方

酵素剈が今後どのように酒類製造に利用されるかにつ いては，酒類には種類あるいは品目によって原料に差違 があるばかりでなく, 同一品種でもウイスキー類などで は級別の差違により原料の制限があるので，酵素を無制 限に使用することについては大いに問題があります。

現在 2000 分の 1 以下であれば，こうじと併用の場合 認めていますが，これを 1000 分の 1 以下にするか，こ らじと併用しない場合も認めてゆくか（例えばビール， 
ウイスキー類）等については業界が真に要望し，品質の 向上, 酒造の合理化および技術の進展が図られるなら ば，前向きの姿勢で検討すべきものと考光られます。も ちろん現在の酒類の種類あるいは品目がある以上は，こ の範囲内です。

ちなみに，清酒醸造の場合，原料でんぷんの500 分の 1 まででんぷん分解酵素剂をすればこうじを使用しなく ても清酒醸造は可能です。

\section{II 最近の酒類添加物等の問題点}

酵素剂以外にも炭酸ガス入り清酒にクエン酸の添加を 認めたり, 幾つかの問題が出ていますので，最近検討さ れた 2,3 の問題について話したいと思います。

I. 炭酸ガス入り清酒にクエン酸を認めること

清酒にガスを吹き込んで発泡性清酒の販売が，新伸会 の有志の人達によってパンチメイトという銘柄で発売さ れましたが，このようなガス入り清酒には看珀酸のよう に味があとまで残る酸よりも，クエン酸や酒石酸のよう に味が爽快で後に残らない酸の方がよいのではないかと いうことで業界から要望がありましたので，いろいろ検 討した結果，クエン酸は清酒中にも相当量含まれている から認め, 酒石酸は清酒には存在しないから認めないと いらことになりました。

糖分等については現行のま李，酒精分 $10 \%$ の時 $8 \%$ を越光ないようにする。したがってアルコール分 $8 \%$ の 時は $8 \times 0.8=6.4 \%$ ということになります。

炭酸入り清酒が売れないで庫に戻し入れられた場合の 問題も女りますので承認基準を変えて，(琥珀酸，乳酸） の他にクエン酸も使用でさるよう尤る考光もあります。

現在の市販製品はアルコール $8 \%$ ，糖分 $6.4 \%$, 酸度 2 , 炭酸ガス圧 $2.6 \mathrm{k} / \mathrm{cm}^{2}$ 程度のものです。

2. 高濃度酒精清酒について

(1) 酒精分 36 度の清酒

名古屋局清水税務署管内の英君酒造さんから申請の女
ったもので 36 度の酒精分の清酒の販売を認めて注しい といらことです。この清酒を造るためには三増に使用す るアルコールは加水せずに 90〜95\% のままで使用する ことになりますので，こんな濃い酒精の使用を認めるか どらか，また 36 度もアルコール分があればリキュール ではないか等の問題もありましたが，検定時で既に酒清 として認めているではないかということと，いろいろの 種類の清酒が出るのは結構ではないかといらことで認め ることにしました。な物，現在この清酒はサンロックの 銘柄で全国的にグループをつくりつつあります。

（2） 酒精分 25 度の清酒

福岡局管内の佐賀銘醉さんが中心になって，いわゆる 「オルフアン 25」の統一銘柄で全国 14 業者が 5 月 1 日 一斉に販売いたしました。

問題は岕まり岕りませんでしたが，市販酒の成分はア ルコール分 25 , 酸度 2 , 清酒メートルは -25 です。

（3）清酒メートル - 30 の合成清酒について

名古屋国税局の岐阜県の間酒造さんから申請されたも ので，アルコール分は 13\%，清酒メートルー30 の合成 清酒を販売したいということですが，アルコール度数が この程度の清酒で，こんな甘口のものがないから，リキ ユールにすべきではないかといら考方方もありました が，実際にこの成分内容の合成清酒を造って味わってみ ますと, 香りも類も清酒に類似して打り, 多少甘い程度 ですから当然合成清酒として認めることにしました。

なお，上述のオルファン 25 とくらべますとオルフォ ン 25 の方がはるか心甘口であることはいうまでも岕り ません。

\section{あとがき}

以上の他にもいろいろと問題が上っておりますが，前 述しましたように当方としては広く業界のためにという 点を考光, 技術の向上, 合理化という点を加味しながら 常々前向きの姿勢で検討している次第です。

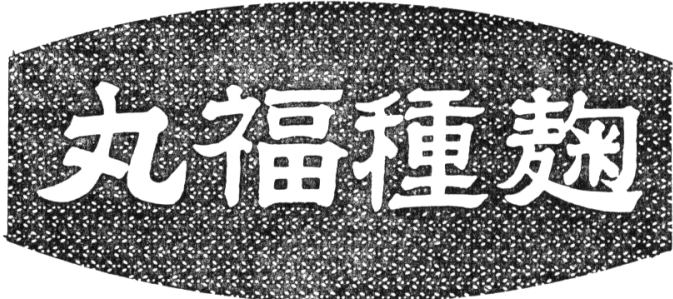

\section{日本醸造工業株式会社}

東京都文京区小石川 $3-26-3$

第 2 事業部

電話 $03-814-2738$ (代)

郵便番号 112 